\title{
Effect of intercropping wheat with forage legumes on wheat production and ground cover ${ }^{(1)}$
}

\author{
Gilberto Omar Tomm ${ }^{(2)}$ and Robert Kerry Foster ${ }^{(3)}$
}

\begin{abstract}
The use of winter legumes in southern Brazil is hindered by the slow growth of these species during establishment exposing soil surface to erosion. Introduction of these species along with spring wheat (Triticum aestivum L.) was studied as a means of increasing ground cover during their initial establishment period, without reducing wheat grain yield. Two experiments were conducted in nearby areas, one in each year. Birdsfoot trefoil (Lotus corniculatus L.), red clover (Trifolium pratense L.) cultivar Quiñequelli, white clover (T. repens L.), and arrowleaf clover (T. vesiculosum Savi) did not reduce cereal yield in either year. Wheat yield was reduced by intercropped red clover cultivar Kenland and by subclover (T. subterraneum L.) in the first year. No grain yield differences due to intercropping with any legume were detected in the second year, when rainfall was below normal. Intercropping with wheat showed to be a practical alternative to enhance ground cover at establishing forage legumes
\end{abstract}

Index terms: Triticum aestivum, feed crops, soil, plant cover, yield components.

\section{Efeito do consórcio entre trigo e leguminosas forrageiras na produção de trigo e na cobertura de solo}

\begin{abstract}
Resumo - O uso de leguminosas forrageiras no sul do Brasil é dificultado pelo lento crescimento dessas espécies no ano de estabelecimento, o que expõe o solo à erosão. Estudou-se a introdução dessas leguminosas concomitantemente ao trigo (Triticum aestivum L.) com o objetivo de aumentar a cobertura de solo durante o seu desenvolvimento inicial, sem reduzir o rendimento de grãos de trigo. Foram realizados dois experimentos em áreas próximas, um em cada ano. O cornichão (Lotus corniculatus L.), o trevo-vermelho (Trifolium pratense L.), cultivar Quiñequelli, o trevo-branco (T. repens L.) e o trevo-vesiculoso (T. vesiculosum Savi) não reduziram o rendimento de trigo em nenhum dos anos. O rendimento de grãos de trigo foi reduzido pelo trevo-vermelho, cultivar Kenland, e pelo trevo subterrâneo (T. subterraneum L.), no primeiro ano. No segundo ano, em que, durante o período de desenvolvimento de trigo, a precipitação pluvial foi inferior à normal, não se observaram diferenças no rendimento de grãos de trigo em decorrência da consorciação com leguminosas. A consorciação com trigo mostrou-se como uma alternativa prática para aumentar a cobertura de solo no estabelecimento de leguminosas forrageiras
\end{abstract}

Termos para indexação: Triticum aestivum, plantas forrageiras, solo, cobertura vegetal, componentes do rendimento.

(1) Accepted for publication on June 15, 2000

Supported by Embrapa and the Canadian International Development Agency (CIDA) - Zero Tillage-Brazil project-204/11727.

(2) Embrapa-Centro Nacional de Pesquisa de Trigo, BR 285, km 174, CEP 99001-970 Passo Fundo, RS.

E-mail: tomm@enpt.embrapa.br

(3)University of Saskatchewan, Crop Development Centre, S7N 0W0 Saskatoon, Saskatchewan, Canada. E-mail: k.foster@sk.sympatico.ca

\section{Introduction}

Adoption of forage legumes by farmers in southern Brazil is restricted by their low productivity and slow growth during the year of establishment. During this initial period a large proportion of soil surface remains exposed and, thus, susceptible to erosion.

Rolling topography combined with highly erosive rains are common in the state of Rio Grande do Sul, 
RS (Cogo et al., 1978) and most of southern Brazil. Without plant cover, soil losses can be as high as (13 metric ton ha-1) over a 100-day period (Wünshe $\&$ Denardin, 1978). The effectiveness of plant cover in reducing erosion was well demonstrated in Zimbabwe. Mean annual soil losses were reduced from 46.3 ton ha ${ }^{-1}$ on bare ground to only 0.4 ton ha $\mathrm{ha}^{-1}$ where protective vegetation ground cover was present (Hudson, 1981).

The object of this study was to evaluate the possibility of increasing ground cover during the establishment of legume cover crops by intercropping them with spring wheat and to identify legume species that do not reduce wheat grain yield.

\section{Material and Methods}

This study was conducted at Embrapa, in Passo Fundo, southern Brazil ( $28^{\circ} 15^{\prime} \mathrm{S}, 52^{\circ} 24^{\prime} \mathrm{W}, 640$ m altitude). Average annual rainfall is $1,763 \mathrm{~mm}$ with a June through November (wheat growing season) rainfall accumulation of $944 \mathrm{~mm}$. The lowest normal (30 year average) monthly precipitation is $100 \mathrm{~mm}$ (May), and the highest is $197 \mathrm{~mm}$ (September). The highest mean monthly maximum temperature is $28.4^{\circ} \mathrm{C}$ in January, and the lowest mean monthly minimum temperature is $9.0^{\circ} \mathrm{C}$ in July (Boletim Agrometeorológico, 1989).

Two experiments were conducted, one in 1987/88 and another in 1988/89, in areas $20 \mathrm{~m}$ apart. The soil at the experimental site is a dystrophic Dark-Red Latosol (Haplorthox), mapping unit Passo Fundo. Initial soil properties were $\mathrm{pH} 6.0$; organic matter, $3.8 \% ; \mathrm{K}, 86 \mathrm{mg} \mathrm{L}^{-1}$; $\mathrm{P}$, $12.5 \mathrm{mg} \mathrm{L}^{-1}$; exchangeable $\mathrm{Al}, \mathrm{Ca}$ and $\mathrm{Mg}, 0,6.3$ and $3.2 \mathrm{cmol}_{\mathrm{c}} \mathrm{L}^{-1}$, respectively.

In both experiments, $200 \mathrm{~kg} \mathrm{ha}^{-1}$ of a 1:1 blend of mono-ammonium phosphate and potash was broadcast and incorporated using a disc harrow. A further $40 \mathrm{~kg} \mathrm{ha}^{-1}$ of $\mathrm{N}$ in the form of urea (45-0-0) was broadcast on $13 \mathrm{Au}-$ gust 1987 and 21 July 1988 on both sole crop spring wheat (Triticum aestivum L.), cultivar BR 14, and the intercropped treatments. In 1988, a treatment was included with no topdressed $\mathrm{N}$ to create more favourable conditions for legume $\mathrm{N}_{2}$ fixation. Management practices generally were selected with the intention of maximizing wheat yield. Weed control by hand weeding or hoeing was done whenever needed.

In the 1987/88 experiment, one serradella, two vetches, six clovers, and three trefoils were evaluated, with characteristics as follows: pink serradela (Ornithopus sativus Brot.), cultivar Common; hairy vetch (Vicia villosa Roth), cultivar Ostsaat; common vetch (Vicia sativa L.), cultivar Common; crimson clover (Trifolium incarnatum L.), cultivar Common; white clover (T. repens L.), cultivar Jacuí S-2; red clover (T. pratense L.), cultivar Kenland; red clover (T. pratense L.), cultivar Quiñequelli; arrowleaf clover (T. vesiculosum Savi), cultivar Yuchi; subclover (T. subterraneum L.), cultivar Clare; Lotus subbiflorus Lag., cultivar Rincon. For further study in the 1988/89 experiment the following forage legumes were selected from this group: big trefoil, cultivar Maku; birdsfoot trefoil, cultivar São Gabriel; white clover, cultivar Jacuí S-2; red clover, cultivar Quiñequelli; arrowleaf clover, cultivar Yuchi; subclover, cultivar Clare; and birdsfoot trefoil, cultivar São Gabriel.

The experiments were laid out as a split-plot design with three replicates in 1987/88 and as a randomized complete block design (RCBD) with three replicates in $1988 / 89$. During the $1987 / 88$ experiment, randomization was restricted within each replicate by placing the intercropped wheat treatments together, in order to facilitate field operations. Legumes were used as main plots and cropping systems (sole legume or intercropped with wheat) as subplots $(2$ by $5 \mathrm{~m}$ ). Plots measured 3 by $8 \mathrm{~m}$ in the $1988 / 89$ experiment. Wheat seeding rates for the $1987 / 88$ and 1988/89 experiments were 240 and 330 viable seeds $\mathrm{m}^{-2}$, respectively. Legume seeds were inoculated with peat based inoculants and then broadcast. Wheat was seeded in rows spaced $20 \mathrm{~cm}$ apart. A commercial drill with double disc openers was used to seed wheat and incorporate legume seeds at the minimal possible depth (1 to $3 \mathrm{~cm})$.

The experiments were seeded on 25 June 1987 and 26 June 1988. Precipitation deficit in relation to the evaporative demand (Class A pan evaporation) suggests that no moisture stress for plant growth occurred from June (seeding) up to the end of October 1987 in the 1987/88 test. The 1988 wheat growing season (June-November) was initially very dry with higher $(177 \mathrm{~mm})$ evaporative demand than precipitation occurring during July and August. The low rainfall in July and August combined with above normal air temperatures in August resulted in a major moisture deficit. These conditions resulted in a stressful early growing season for legume establishment. The weather conditions for plant growth during the wheat growing season can be summarized as close to normal during 1987 and abnormally dry in 1988 (Tomm, 1990).

All field data were subjected to analysis of variance (ANOVA). All single wheat variables (in both experiments) were tested as RCBD. Data transformations were done by $y=1 /(X+1)$, whenever necessary, as determined by the $\mathrm{F}$ max procedure at $\mathrm{P}<0.05$ (David, 1952) to fulfill the 
assumption of homogeneity of variances required for a valid ANOVA (Steel \& Torrie, 1980). Information on the variables that were transformed is provided along with the respective data on tables.

All mean comparisons were made at $\mathrm{P} \leq 0.05$. In order to detect minimal significant effects of intercropping on wheat, the Fisher's protected LSD test was used for wheat variables (whenever $\mathrm{P}<0.05$ ). On all other mean comparisons the Student-Newman-Keuls' (SNK's) test was used Information is provided whenever mean separation by both tests was equal. Analyses were run on SAS Version 5.18 (Statistical Analysis System Institute, 1985).

Wheat grain yields were obtained from sample areas measuring 4 and $12 \mathrm{~m}^{2}$ in 1987 and 1988, respectively. The time to legume emergence was determined when $80 \%$ of seedlings had emerged. Legume plant density was counted on $1 \mathrm{~m}^{2}$ square samples. In the $1987 / 88$ experiment, one evaluation was done on 5 August, while the 1988/89 experiment had two evaluations (22 July and 18 August) Red clover, subclover, wheat + red clover, and wheat + subclover treatments were evaluated on 22 July 1988 During 1988, at date of first counting, certain legumes had still not reached complete emergence. For this reason white clover, arrowleaf clover, birdsfoot trefoil, wheat + white clover, wheat + arrowleaf clover, and wheat + birdsfoot trefoil treatments were evaluated on 18 August 1988.

Ground cover by crop residues was estimated on an area basis instead of residues dry weight. Measurement of ground cover on an area basis is considered more advantageous than dry weight of residues because the former has a direct relationship to raindrop interception regardless of residue type. The latter varies depending on the type of crop residue (Wischmeier, 1973). Ground cover throughout this study was visually evaluated on a percentage basis. This evaluation was done by visually separating the uncovered ground area from the plant ground covered portions of each plot. Estimates for each plot were determined by calculating the observations taken from two individuals.

\section{Results and Discussion}

Average yield of wheat cultivar BR 14 in a large number of trials (1982 to 1984), in Rio Grande do Sul, was $224 \mathrm{~g} \mathrm{~m}^{-2}$ (Embrapa, 1985). Grain yield of single wheat topdressed with $40 \mathrm{~kg} \mathrm{ha}^{-1}$ of $\mathrm{N}$ was 43 and 32\% lower (Table 1) in the 1987 and 1988 seeded experiments, respectively, than the $1982 / 84$ average yield trials.
The grain yield of wheat intercropped with either white clover, birdsfoot trefoil, arrowleaf clover or red clover cultivar Quiñequelli was not lower than single wheat topdressed with $40 \mathrm{~kg} \mathrm{ha}^{-1}$ of $\mathrm{N}$ in 1987 and 1988 (Table 1). However, red clover cultivar Kenland and subclover had a negative effect on wheat yield in 1987. Similarly, Brandt et al. (1989), found that grain yield of winter wheat did not decrease by intercropping with any of the four subclover cultivars in the first year. Wheat grain yield was, however, increased by at least $84 \%$ in the following season when both crops were repeated in the same area. This was attributed to the nitrogen contribution from residue of the previous subclover crop.

Hairy and common vetch displayed tall growth habits which hindered wheat grain harvest. These vetches were therefore not considered suitable for use in this cropping system. Red clover cultivar Quiñequelli displayed a more favourable production pattern than the cultivar Kenland and was thus selected for further study in 1988 .

In 1988, no wheat yield differences due to intercropping with any legume were detected (Table 1).

Table 1. Grain yield of wheat and wheat intercropped with various legumes at Passo Fundo in 1987 and $1988^{(1)}$.

\begin{tabular}{lcc}
\hline Treatment & \multicolumn{2}{c}{ Wheat yield $\left(\mathrm{g} \mathrm{m}^{-2}\right)$} \\
\cline { 2 - 3 } & 1987 & 1988 \\
\hline Wheat + 40 kg ha ${ }^{-1}$ of $\mathrm{N}$ & $127 \mathrm{abc}$ & $153 \mathrm{a}$ \\
Wheat & --- & $151 \mathrm{a}$ \\
Wheat + pink serradela & $123 \mathrm{abcd}$ & --- \\
Wheat + hairy vetch & $-2)$ & --- \\
Wheat + common vetch & $-(2)$ & --- \\
Wheat + crimson clover & $122 \mathrm{abcd}$ & --- \\
Wheat + white clover & $129 \mathrm{abc}$ & $144 \mathrm{a}$ \\
Wheat + red clover cv. Kenland & $97 \mathrm{de}$ & --- \\
Wheat + red clover cv. Quinequelli & $103 \mathrm{cde}$ & $142 \mathrm{a}$ \\
Wheat + arrowleaf clover & $110 \mathrm{~cd}$ & $138 \mathrm{a}$ \\
Wheat + subclover & $82 \mathrm{e}$ & $143 \mathrm{a}$ \\
Wheat + Lotus subbiflorus & $137 \mathrm{ab}$ & --- \\
Wheat + big trefoil & $142 \mathrm{a}$ & --- \\
Wheat + birdsfoot trefoil & $112 \mathrm{bcd}$ & $144 \mathrm{a}$ \\
\hline Mean & 117 & 145 \\
Pr>F $(\%)$ & 0.01 & 60 \\
CV $(\%)$ & 15 & 7 \\
\hline
\end{tabular}

(1)Means in a column followed by a common letter do not differ $(\mathrm{P} \leq 0.05)$ by Fisher's protected LSD test. (2)Not harvested; legume growth (height) prevented wheat grain harvest. 
This was attributed to restricted growth of the legumes in response to below normal rainfall which occurred during July and August (49 mm vs. a normal of $307 \mathrm{~mm}$ ). Dry conditions continued up to September 10 . The overall mean wheat grain yield was $19.3 \%$ lower in 1987 than in 1988 (Table 1).

During September and October 1987, symptoms of barley yellow dwarf virus (BYDV) were evenly distributed on wheat plants throughout the experiment. In the same period, symptoms of powdery mildew, caused by Erysiphe graminis f. sp. tritici, were at economic damaging levels requiring a fungicide application. Wheat BR 14 is a cultivar moderately susceptible to BYDV and susceptible to powdery mildew (Embrapa, 1985). Wiese (1977) recorded wheat yield losses of up to $40 \%$ due to powdery mildew, mainly caused by a reduction in head numbers and kernel weight. In this study the wheat thousand kernel weight on the single wheat $+40 \mathrm{~kg} \mathrm{ha}^{-1}$ of $\mathrm{N}$ treatment was $17.3 \%$ (6.1 g) lower in 1987 than in 1988. The number of spikes per tiller averaged over all treatments was $1.2 \%$ lower $(0.504$ vs. 0.510$)$ in 1987 than in 1988 (Table 2). The number of spikes per plant was lower (21.6\%) as well (0.913 vs. 1.164$)$ (Table 2). In the period under consideration the soil was near water saturation showing signs of runoff flow. Under such conditions, $\mathrm{N}$ losses by denitrification, leaching and erosion could be expected. The combination of damage by diseases (BYDV and powdery mildew) and insufficient $\mathrm{N}$ supply are suggested as causes for the chlorotic leaf appearance and the lower yield in the single wheat $+40 \mathrm{~kg} \mathrm{ha}^{-1}$ of $\mathrm{N}$ treat- ment in 1987 than in 1988. In addition, young volunteer black oat plants (Avena strigosa) were not easily distinguished from wheat plants and may have competed with the seeded crops. Those yield depressing factors evident in the $1987 / 88$ experiment were not noticeable in the 1988 seeded experiment.

No significant differences in the number of spikes $\mathrm{m}^{-2}$ were detected between any treatments during either the 1987 or the 1988 seeded experiment (Table 2). In 1987 the average number of spikes $\mathrm{m}^{-2}$ was $62 \%$ lower than in 1988 . The mean number of kernels spike ${ }^{-1}$ in the 1987 experiment was 21 (Table 2). This parameter was not evaluated in 1988. No thousand kernel weight differences were detected in 1987 . The overall treatments mean was $27.8 \mathrm{~g}(\mathrm{Pr}>\mathrm{F} 65 \%$; CV 4\%). In the 1988 seeded experiment the thousand kernel weight of single wheat + $40 \mathrm{~kg} \mathrm{ha}^{-1}$ of $\mathrm{N}(35.3 \mathrm{~g})$ was significantly different (Pr>F 3.2\%; CV 0.6\%) from all other treatments $(35.9 \mathrm{~g})$, including single wheat (with no $\mathrm{N}$ topdressed), by both Fisher's Protected LSD and SNK's tests. This data is in agreement with Brandt et al. (1989), who also found no effect of intercropping clover cultivars on wheat yield components during the first year.

In addition to the wheat yield components, six wheat phenological parameters were evaluated. These additional parameters showed no statistical difference among treatment means in either the 1987 or 1988 seeded experiments (Table 2). The number of plants, tillers and spikes per unit area was 51\%, 61\% and $62 \%$, respectively, lower in the 1987 seeded experiment than in the succeeding year (Table 2).

Table 2. Wheat phenological parameters with non significant differences among treatments at Passo Fundo in 1987 and 1988 .

\begin{tabular}{|c|c|c|c|c|c|c|}
\hline \multirow[t]{2}{*}{ Parameter } & \multicolumn{2}{|c|}{ Treatment mean $^{(1)}$} & \multicolumn{2}{|c|}{$\mathrm{CV}$} & \multicolumn{2}{|c|}{ Significance of $F(P R>F)$} \\
\hline & 1987 & 1988 & 1987 & 1988 & 1987 & 1988 \\
\hline & & & ------ & ------- & ----- & ------- \\
\hline Height (cm) & 86.2 & 82.2 & 3.1 & 4.5 & 84.5 & 93.1 \\
\hline Plants $\mathrm{m}^{-2}$ & 177.2 & 362.6 & 11.9 & 9.7 & 28.1 & 73.4 \\
\hline Tillers $\mathrm{m}^{-2}$ & 320.8 & 827.4 & 12.6 & 8.6 & 17.8 & 61.3 \\
\hline Spikes $\mathrm{m}^{-2}$ & 161.7 & 422.0 & 13.7 & 8.1 & 78.2 & 18.1 \\
\hline Grams spike ${ }^{-2}$ & 0.6 & 0.4 & 13.2 & 13.6 & 32.0 & 93.9 \\
\hline Kernels spike $^{-2}$ & 21.2 & $n d^{(2)}$ & 9.9 & $\mathrm{nd}^{(2)}$ & 14.6 & $\mathrm{nd}^{(2)}$ \\
\hline Test weight $\left(\mathrm{kg} \mathrm{hL}^{-1}\right)$ & 78.6 & 78.4 & 1.1 & 0.4 & 38.7 & 56.2 \\
\hline Seed germination $(\%)$ & 85.8 & 91.9 & 3.4 & 3.0 & 23.6 & 79.7 \\
\hline
\end{tabular}

${ }^{(1)}$ Combined means due to lack of significant difference between single and intercropped treatments. ${ }^{(2)}$ Not determined. 
The larger number of spikes in the 1988 seeded experiment was partially compensated by the lower spike yield (grams spike ${ }^{-1}$ ) which was two thirds of that in the preceding year (Table 2). A cultivar description for BR 14, based on observations in 1983 and 1984, stated average spikes $\mathrm{m}^{-2}$ of 369 and 480 , respectively (Embrapa, 1985). The data for this parameter in 1988 was very close to the average of these two observations (Table 2). During 1987 the number of spikes $\mathrm{m}^{-2}$ was well below these reference values.

Height of BR 14 evaluated in the 1983 and 1984 trials was 86 and $98 \mathrm{~cm}$, respectively (Embrapa, 1985). In the 1987 and 1988 seeded experiments the mean wheat plant height (Table 2) was close to the average of the 1983 trials and well below the 1984 heights, respectively.

The drier weather conditions experienced during 1988 were more restrictive to the development of wheat plant diseases than those occurring in 1987. A lower incidence of plant diseases may explain the higher mean seed germination observed in 1988 (Table 2).

Ground cover evaluated eight weeks following seeding was variable for the different legumes when grown as single crops (Table 3 ). More consistent ground cover was obtained on intercropped treatments. Ground cover was influenced by both date of emergence and plant density of the legume. The time required from seeding to legume emergence has a major influence on ground cover. During 1988 legume emergence date (Table 4) for single crop treatments had a more marked effect on ground cover than did the plant density (Table 5). In single legume treatments, later emerging species (white clover, birdsfoot trefoil, and arrowleaf clover) produced smaller ground cover than earlier emerging species (red clover and subclover).

The influence of legume time to emergence (Table 4) on ground cover was especially noticeable in the 1988 seeded experiment. Birdsfoot trefoil and white clover emerged five and seven weeks, respectively, after seeding, while red clover and subclover emerged in less than two weeks. Red clover was consistently the first species to emerge while white clover was the last. White clover emerged later in both experiments. The late emergence in 1988 reduced its
Table 3. Percentage ground cover occurring in wheat, legumes, and wheat intercropped with legumes measured eight weeks following seeding at Passo Fundo in 1987 and $1988^{(1)}$.

\begin{tabular}{|c|c|c|c|c|}
\hline \multirow[t]{3}{*}{ Treatment } & \multicolumn{4}{|c|}{ Ground cover ${ }^{(2)}$} \\
\hline & \multicolumn{2}{|c|}{1987} & \multicolumn{2}{|c|}{1988} \\
\hline & Single & $\overline{\text { Intercrop }}$ & Single & Intercrop \\
\hline Wheat $+40 \mathrm{~kg} \mathrm{ha}^{-1}$ of $\mathrm{N}$ & $62 \mathrm{ef}$ & -- & $56 \mathrm{c}$ & -- \\
\hline Wheat & -- & -- & $61 \mathrm{c}$ & -- \\
\hline Pink serradela & $36 \mathrm{~h}$ & 75abcde & -- & -- \\
\hline Hairy vetch & 70 bcde & $86 a b c$ & -- & -- \\
\hline Common vetch & $52 \mathrm{fg}$ & 74abcde & -- & -- \\
\hline Crimson clover & $29 \mathrm{~h}$ & 75 abcde & -- & -- \\
\hline White clover & $30 \mathrm{~h}$ & $68 \mathrm{cde}$ & $2 \mathrm{f}$ & $62 \mathrm{c}$ \\
\hline Red clover cv. Kenland & 69 cde & $85 \mathrm{abcd}$ & -- & -- \\
\hline Red clover cv. Quiñequelli & 77abcde & $88 \mathrm{ab}$ & $55 \mathrm{c}$ & $72 \mathrm{ab}$ \\
\hline Arrowleaf clover & $43 \mathrm{gh}$ & 76abcde & $34 \mathrm{~d}$ & $62 \mathrm{c}$ \\
\hline Subclover & 81 abcde & $92 a$ & $63 c$ & $78 \mathrm{a}$ \\
\hline Lotus subbiflonus & $11 \mathrm{i}$ & $67 \mathrm{de}$ & -- & -- \\
\hline Big trefoil & $8 \mathrm{i}$ & $65 \mathrm{ef}$ & -- & -- \\
\hline Birdsfoot trefoil & $37 \mathrm{~h}$ & $71 \mathrm{bcde}$ & $11 \mathrm{e}$ & $65 \mathrm{bc}$ \\
\hline Mean & \multicolumn{2}{|c|}{61} & \multicolumn{2}{|c|}{52} \\
\hline $\operatorname{Pr}>\mathrm{F}(\%)$ & \multicolumn{2}{|c|}{0.01} & \multicolumn{2}{|c|}{0.01} \\
\hline $\mathrm{CV}(\%)$ & \multicolumn{2}{|c|}{11} & \multicolumn{2}{|c|}{8} \\
\hline
\end{tabular}

(1)Means within or between cropping systems followed by a common letter do not differ $(\mathrm{P} \leq 0.05)$ by the SNK's test. ${ }^{(2)}$ Evaluated at 54 and 53 days after seeding in 1987 and 1988 , respectively.

Table 4. Time from legume seeding to emergence at Passo Fundo, 1987 and $1988^{(1)}$.

\begin{tabular}{|c|c|c|c|}
\hline \multirow[t]{2}{*}{ Legume species } & \multirow{2}{*}{$\frac{1987}{\text { Combined }^{(2)}}$} & \multicolumn{2}{|r|}{1988} \\
\hline & & Single & $\overline{\text { Intercropped }}$ \\
\hline & \multicolumn{3}{|c|}{--- Weeks to emergence - - } \\
\hline Pink serradela & $3.2 \mathrm{c}$ & -- & -- \\
\hline Hairy vetch & $3.0 \mathrm{c}$ & - & -- \\
\hline Common vetch & $3.0 \mathrm{c}$ & -- & -- \\
\hline Crimson clover & $3.0 \mathrm{c}$ & -- & -- \\
\hline White clover & $4.8 b$ & $7.0 \mathrm{a}$ & $7.0 \mathrm{a}$ \\
\hline Red clover cv. Kenland & $2.0 \mathrm{~d}$ & -- & -- \\
\hline Red clover cv. Quiñequelli & $2.0 \mathrm{~d}$ & $1.0 \mathrm{~d}$ & $1.0 \mathrm{~d}$ \\
\hline Arrowleaf clover & $3.2 \mathrm{c}$ & $3.7 \mathrm{c}$ & $4.7 \mathrm{~b}$ \\
\hline Subclover & $2.0 \mathrm{~d}$ & $1.3 \mathrm{~d}$ & $1.3 \mathrm{~d}$ \\
\hline Lotus subbiflorus & $4.7 b$ & -- & -- \\
\hline Big trefoil & $5.7 \mathrm{a}$ & -- & -- \\
\hline Birdsfoot trefoil & $3.0 \mathrm{c}$ & $5.0 \mathrm{~b}$ & $5.0 \mathrm{~b}$ \\
\hline Mean & 3.3 & \multicolumn{2}{|r|}{3.7} \\
\hline $\operatorname{Pr}>\mathrm{F}(\%)$ & 0.01 & \multicolumn{2}{|r|}{0.01} \\
\hline $\mathrm{CV}(\%)$ & 3.5 & \multicolumn{2}{|c|}{10.0} \\
\hline
\end{tabular}

(1) Means in a column (1987) and within or between cropping systems (1988) followed by a common letter do not $\operatorname{differ}(\mathrm{P} \leq 0.05)$ by both Fisher's Protected LSD and SNK's tests. ${ }^{(2)}$ Combined means due to lack of significant difference between single and intercropped treatments; means separation on transformed data. 
ability to produce any significant ground cover by the eight weeks. Birdsfoot trefoil on single and intercropped treatments and intercropped arrowleaf clover in the 1988 seeded experiment showed similar patterns. Those differences in the time to emergence are likely related to the fact that white clover and birdsfoot trefoil are perennials whereas red clover is biennial or short lived perennial, and subclover, serradela, hairy vetch, common vetch, crimson clover, and arrowleaf clover are annual species.

Legume plant density in both experiments (Table 5) had a smaller influence on ground cover in intercropped treatments at eight weeks (Table 3) than the influence of legume emergence date. In the 1987 seeded experiment no difference was found in legume plant density between single and intercropped treatments. In 1988 a significant difference in plant density was detected between single and intercropped white clover (Table 5). No differences in plant density were detected in 1988 for red clover cultivar Quiñequelli, arrowleaf clover, subclover, and birdsfoot trefoil. For all species the plant density obtained was lower than expected, when compared to the number of viable seeds planted (Table 5).

Intercropping wheat with subclover, hairy vetch or either of the red clover cultivars, in the 1987 seeded experiment, did not increase ground cover when compared to swards of the same legume as sole crop (Table 3). In the same experiment, however, intercropping with wheat significantly enhanced ground cover as compared to sole crops of pink serradella, common vetch, crimson clover, white clover, arrowleaf clover, Lotus subbiflorus, big trefoil, and birdsfoot trefoil. Intercropping in 1988 significantly increased ground cover, at eight weeks after seeding, when compared to all single legume treatments (Table 3).

Ground cover at eight weeks after seeding on sole legume crops was from $8 \%$ to $81 \%$ in the $1987 \mathrm{ex}$ periment and $2 \%$ to $63 \%$ in the 1988 experiment. In contrast, intercrops in both years provided a minimum of $62 \%$ ground cover (up to $92 \%$ ) (Table 3 ).

Table 5. Number of seeds planted and corresponding established plant density of legume species at Passo Fundo.

\begin{tabular}{|c|c|c|c|c|}
\hline \multirow[t]{3}{*}{ Legume species } & \multirow[t]{3}{*}{ Seeds sown ${ }^{(1)}$} & \multicolumn{3}{|c|}{ Plant density $^{(2)}$} \\
\hline & & \multirow{2}{*}{$\begin{array}{c}1987^{(3)} \\
\text { Combined means }\end{array}$} & \multicolumn{2}{|c|}{$1988^{(4)}$} \\
\hline & & & Single & Intercropped \\
\hline & $\left(\right.$ seeds $\left.\mathrm{m}^{-2}\right)$ & \multicolumn{3}{|c|}{ - } \\
\hline Pink serradela & 520 & $119 \mathrm{e}$ & -- & -- \\
\hline Hairy vetch & 45 & $44 \mathrm{f}$ & -- & -- \\
\hline Common vetch & 60 & $58 \mathrm{f}$ & -- & -- \\
\hline Crimson clover & 430 & $73 \mathrm{ef}$ & -- & -- \\
\hline White clover & 270 & $83 \mathrm{ef}$ & $25 b$ & $17 \mathrm{c}$ \\
\hline Red clover cv. Kenland & 1,250 & $401 b$ & -- & -- \\
\hline Red clover cv. Quiñequelli & 1,750 & $489 \mathrm{a}$ & $1,444 \mathrm{a}$ & $1,526 \mathrm{a}$ \\
\hline Arrowleaf clover & 500 & 92ef & $110 \mathrm{a}$ & $103 a$ \\
\hline Subclover & 300 & $259 \mathrm{c}$ & $219 a$ & $246 \mathrm{a}$ \\
\hline Lotus subbiflomis & 370 & 93ef & -- & -- \\
\hline Big trefoil & 370 & $65 \mathrm{ef}$ & -- & -- \\
\hline Birdsfoot trefoil & 370 & $188 \mathrm{~d}$ & $258 \mathrm{a}$ & $87 \mathrm{a}$ \\
\hline Mean & 520 & 164 & & \\
\hline $\operatorname{Pr}>\mathrm{F}(\%)$ & & 0.01 & & \\
\hline $\mathrm{CV}(\%)$ & & 19 & & \\
\hline
\end{tabular}

${ }^{(1)}$ The number of seeds sown was corrected for germination. (2)Measured 41 days after seeding in 1987 and 26 or 53 days after seeding in 1988 . (3) Combined means due to lack of significant difference between single and intercropped treatments; means in a column followed by a common letter do not differ $(\mathrm{P} \leq 0.05)$ by the SNK's test. (4)Means within or between cropping systems followed by a common letter do not differ ( $\mathrm{P} \leq 0.05)$ by both Fisher's protected LSD and SNK's tests; means separation on transformed data 
The lowest ground cover occurred intercropping wheat with white clover, while the highest was observed using subclover. These results were similar in both near normal and very dry growing seasons. These results suggest that intercropping wheat with certain legumes can be used to reduce the risk of poor ground cover on a field in which legumes are being established.

\section{Conclusions}

1. Intercropping with wheat is a practical alternative to enhance ground cover at establishing forage legumes and a minimum of $62 \%$ ground cover can be expected eight weeks following seeding.

2. Intercropping white clover, red clover cultivar Quiñequelli, arrowleaf clover or birdsfoot trefoil with wheat does not reduce cereal grain yield either in normal or below normal precipitation growing seasons.

3 . No wheat grain yield reductions due to intercropping with forage legumes are likely under higher evaporative demand than precipitation during the first 70 days after seeding.

\section{References}

BOLETIM AGROMETEOROLÓGICO 1988. Passo Fundo : Embrapa-CNPT, 1989. 34 p.

BRANDT, J. E.; HONS, F. M.; HABY, V. A. Effects of subterranean clover interseeding on grain yield, yield components, and nitrogen content of soft red winter wheat Journal of Production Agriculture, Madison, v. 2, p. $347-$ 351,1989
COGO, N. P.; DREWS, C. R.; GIANELLO, D. C. Índices de erosividade das chuvas dos municípios de Guaíba, Ijuí e Passo Fundo, no Estado do Rio Grande do Sul. In: ENCONTRO NACIONAL DE PESQUISAS SOBRE CONSERVAÇÃO DO SOLO, 2., 1978, Passo Fundo. Anais... Passo Fundo : Embrapa-CNPT, 1978. p. 145-152.

DAVID, H. A. Upper 5 and $1 \%$ points of the maximum F-ratio. Biometrika, Oxford, v. 39, p. 422-424, 1952

EMBRAPA. Centro Nacional de Pesquisa de Trigo (Passo Fundo, RS). Cultivar BR 14. Passo Fundo, 1985. 10 p.

HUDSON, N. W. Soil conservation. Ithaca : Cornell University, $1981.324 \mathrm{p}$

STATISTICAL ANALYSIS SYSTEM INSTITUTE (Cary, Unites States). SAS users guide: statistics version. 5. ed. Cary, 1985. $956 \mathrm{p}$

STEEL, R. G. D.; TORRIE, J. H. Principles and procedures of statistics: a biometrical approach. New York : McGraw-Hill, 1980. 633 p.

TOMM, G. O. Wheat intercropped with forage legumes in Southern Brazil. Saskatoon : University of Saskatchewan, 1990. 122 p. M.Sc. Thesis.

WIESE, M. V. Compendium of wheat diseases. St. Paul : American Phytopathological Society, 1977. 106 p.

WISCHMEIER, W. H. Conservation tillage to reduce water erosion. In: NATIONAL CONFERENCE CONSERVATION TILLAGE, 1973, Ankeny. Proceedings... Ankeny : Soil Conservation Society of America, 1973. p. 133-141.

WÜNSHE, W.A.; DENARDIN, J.E. Perdas de solo e escorrimento de água sob chuva natural em Latossolo Vermelho-Escuro nas culturas de trigo e soja. In: ENCONTRO NACIONAL DE PESQUISAS SOBRE CONSERVAÇÃO DO SOLO, 2., 1978, Passo Fundo Anais... Passo Fundo : Embrapa-CNPT, 1978. p. 289-293. 